\title{
Article \\ Characterization of Biobriquettes Produced from Vineyard Wastes as a Solid Biofuel Resource
}

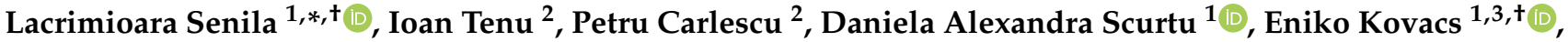

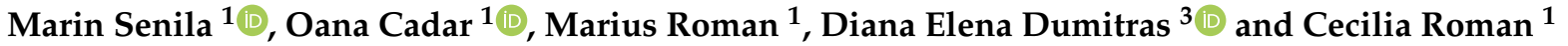

1 Research Institute for Analytical Instrumentation Subsidiary, National Institute for Research and Development of Optoelectronics Bucharest INOE 2000, 67 Donath Street, 400293 Cluj-Napoca, Romania; daniela.scurtu@icia.ro (D.A.S.); eniko.kovacs@icia.ro (E.K.); marin.senila@icia.ro (M.S.); oana.cadar@icia.ro (O.C.); marius.roman@icia.ro (M.R.); cecilia.roman@icia.ro (C.R.)

2 Faculty of Agriculture, University of Agricultural Sciences and Veterinary Medicine, 3 Mihail Sadoveanu Alley, 700490 Iasi, Romania; ioantenu@yahoo.com (I.T.); pcarlescu@yahoo.com (P.C.)

3 Faculty of Horticulture, University of Agricultural Sciences and Veterinary Medicine, 3-5 Manastur Street, 400372 Cluj-Napoca, Romania; ddumitras@usamvcluj.ro

* Correspondence: lacri.senila@icia.ro; Tel.: +40-264-420590

+ These authors contributed equally to this work.

check for updates

Citation: Senila, L.; Tenu, I.; Carlescu, P.; Scurtu, D.A.; Kovacs, E.; Senila, M.; Cadar, O.; Roman, M.; Dumitras, D.E.; Roman, C. Characterization of Biobriquettes Produced from Vineyard Wastes as a Solid Biofuel Resource. Agriculture 2022, 12, 341. https://doi.org/10.3390/ agriculture12030341

Academic Editors: Dongyang Liu and Mariusz J. Stolarski

Received: 21 January 2022

Accepted: 25 February 2022

Published: 27 February 2022

Publisher's Note: MDPI stays neutral with regard to jurisdictional claims in published maps and institutional affiliations.

Copyright: (c) 2022 by the authors. Licensee MDPI, Basel, Switzerland. This article is an open access article distributed under the terms and conditions of the Creative Commons Attribution (CC BY) license (https:// creativecommons.org/licenses/by/ $4.0 /)$.

\begin{abstract}
The large amount of biomass waste generated by vineyard pruning causes many environmental concerns. The production of briquettes represents an alternative to obtaining a value-added product. The transformation of vineyard wastes into briquettes could produce a densified product having high energy potential. The study investigates the production and chemical, structural, and thermal characterization of briquettes. The thermogravimetric analysis (TGA) shows that the briquettes have different stages of decomposition depending on temperature, such as drying, heating, devolatilization, and char aggregation. All the briquettes are decomposed around $600{ }^{\circ} \mathrm{C}$. The analysis by X-ray diffraction (XRD) shows the crystallinity of briquettes. The pollutant emissions resulted from briquettes burning were measured as $444.7 \mathrm{mg} \mathrm{N}^{-1} \mathrm{~m}^{-1}$ nitrogen oxide $\left(\mathrm{NO}\right.$ ), $157.0 \mathrm{mg} \mathrm{N}^{-1} \mathrm{~m}^{-1}$ sulphur dioxide $\left(\mathrm{SO}_{2}\right)$ and $2165.0 \mathrm{mg} \mathrm{N}^{-1} \mathrm{~m}^{-1}$ carbon monoxide $(\mathrm{CO})$. The flue gases are below the admitted limits, with the exception of carbon monoxide content due to the incomplete combustion and high lignin content. Therefore, it can be concluded that briquettes produced from vineyard wastes have similar properties to briquettes produced from wood. This study demonstrates the potential of the obtained briquettes to replace the wood or charcoal through a desulphurization method.
\end{abstract}

Keywords: solid biofuel; vineyard waste; briquettes; flue gases; lignin

\section{Introduction}

The use of renewable raw materials, especially waste and by-products, has become increasingly important. Viticulture is one of the most important agricultural activities in Romania. Vineyard pruning produces a large quantity of wastes which usually are left in the field. The valorification of agricultural residues is extremely important in energy production and utilization of biomass as alternative energy source [1,2]. The interest for the conversion of vineyard biomass into thermal/electrical energy comes not only from the fact that it represents a valuable and renewable source, but also because it offers various advantages in terms of development and environmental protection. The use of renewable sources is a necessity of the present and future civilizations, biomass being an important raw material to ensure the necessary energy. The category of lignocellulosic raw materials includes the vine resulting from the dry cuttings of vine plantations, having a high calorific value. Biomass requirements have steadily increased in the heating, energy, and transportation sectors, with the evolution of the densified solid biofuel production sector. Currently, the interest in fuel briquetting increased due to opportunities to use the agricultural wastes and their transformation into solid fuel $[3,4]$. 
Presently, briquettes are produced from different agricultural residues like straw, husks, bagasse, peels, stalks, shells, stems, and leaves [5-8]. The biomass preprocessing includes cleaning, drying, size reduction, binder addition, and biomass densification [5,9]. The densification processes involve the use of pressure to press the biomass in order to reduce its volume and to agglomerate the material in a compressed state. The non-wood briquettes are a densified product made by compressing ground biomass, with or without additive, with a cubic, prismatic, or cylindrical shape, with a diameter greater than $25 \mathrm{~mm}$. Briquettes can be obtained from biomass by two methods: (i) the biomass is pressed with a piston at high pressure using a hydraulic or mechanical press, with intermittent release, and (ii) the biomass is pressed with a screw, with continuous release. The majority of briquettes are produced in the presence of a binder, such as xanthan gum or guar gum [10-12]. Lignin can act as internal binder at high briquetting pressure. The use of vineyard briquettes can create a market opportunity for agriculture but can also reduce the dependence on coal and the greenhouse emissions [13].

In the literature, there are some studies regarding the production of briquettes from various waste types, such as cashew nut shells and areca nuts [14,15], sawdust admixture [16], sawdust, rice and coconut husks [17], cassava waste [18], banana peel, corn husk and their combination [19], and maize cobs [20,21]. Bot et al. [22] investigated the production process of briquettes from coconut shells, banana peels, sugarcane bagasse, and rattan waste and concluded that from the analyzed waste types, coconut husks had reduced mass loss and good combustion properties. Lubwama et al. [23] demonstrated that rice and coffee husks briquettes had superior thermal efficiency compared to groundnut shells. Briquettes from coffee husks were also studied by Setter et al. [24], revealing the effect of particle size on the mechanical and energy parameters of briquettes and by Tesfaye et al. [25], presenting the benefits of coffee husk briquettes compared to firewood.

Our previous publication reports the methods used for briquettes production from vineyard wastes, but intensive studies about chemical structural and combustion products are needed [26]. The most important quality parameters are durability and stability. The properties of solid biofuels are affected by many characteristics of the biomass, such as the great diversity of species, various habitats, the type, and the nature of the culture. The problems of the agricultural solid biofuels are the sulphur and ash content [27].

The emission studies are very important for the evaluation of pollutants emission and particulate matter, but the majority of the studies reported only on the technology of briquettes obtained from various biomass types, while the combustion experiments are missing. The present paper presents a solution for producing high-quality briquettes from vine shoot waste. The results regarding vineyard pruning valorization were already published, presenting bioethanol production from cellulose extracted from vineyard waste after autohydrolysis and delignification pretreatment [28], pellets production [29], and a preliminary study of briquettes production from vine tendrils [26]. In this regard, this study aims to continue the chemical investigation, structural characterization, and combustion experiments of briquettes obtained from several Romanian vineyard varieties.

\section{Materials and Methods}

\subsection{Chemical and Reagents}

All used chemicals were of analytical reagent grade. Acetic acid, dichloromethane, sulphuric acid (98\%), sodium hydroxide, methanol, hydrochloric acid (37\%), nitric acid $(65 \%)$, sulphuric acid $(98 \%)$, ethanol, toluene, acetone, and hydrogen peroxide $(30 \%)$ were purchased from Merck (Darmstadt, Germany). Sodium chlorite (80\%) was purchased from Alfa Aesar GmbH \& Co (Karlsruhe, Germany). All solutions were prepared by using ultrapure water $\left(18.2 \mathrm{M} \Omega \mathrm{cm}^{-1}\right.$ at $\left.20^{\circ} \mathrm{C}\right)$ obtained from a Direct-Q3 UV Water Purification System (Millipore, France). 


\subsection{Sample Description}

A total of eight Romanian varieties biomass samples were selected from the following varieties: Pinot Noir (PN), Muscat Ottonel (MO), Feteasca Neagra (FN), Feteasca Alba (FA), Feteasca Regala (FR), Cabernet Sauvignon (CS), Sauvignon Blanc (SB), and Busuioaca de Bohotin (BB).

\subsection{Production of Briquettes}

The initial study regarding the production of briquettes from vineyard waste was initiated and the first results were published in our recent paper [26]. The applied technology contains the following steps: collecting the tendrils, storage, natural drying, coarse and fine grinding, sieving and separation of the particles between 3.15 and $8 \mathrm{~mm}$, and briquetting. The obtained briquettes were characterized and the information about moisture, heating value, and physical characteristics were reported. The obtained Pini Kay briquettes have a moisture content around $10 \%$, a diameter of $58 \mathrm{~mm}$, a length of around $200 \mathrm{~mm}$, a bulk density of around $650 \mathrm{~kg} \mathrm{~m}^{-3}$, a unit density of $1300 \mathrm{~kg} \mathrm{~m}^{-3}$, and a mechanical durability of $95 \%$ (Figure 1).

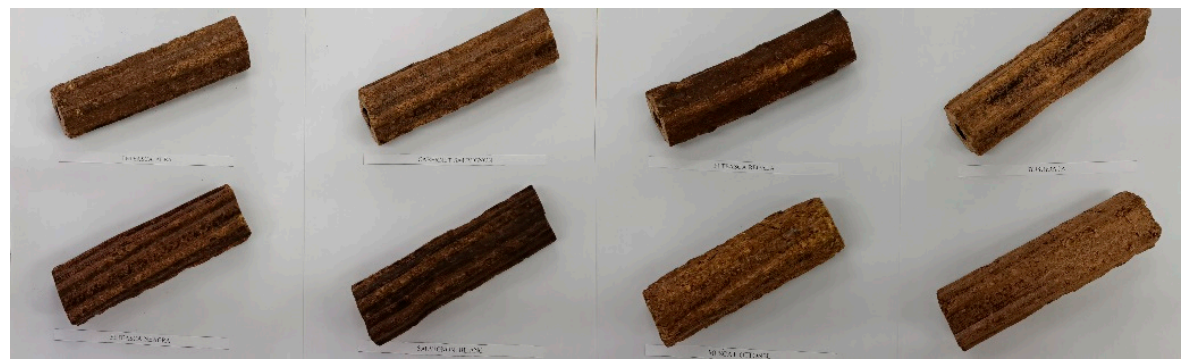

Figure 1. Briquettes obtained from vine shoot waste varieties.

\subsection{Chemical Characterization of Briquetted Obtained from Vineyard Waste}

2.4.1. Carbohydrate and Lignin Analysis

The content of carbohydrates from the briquettes was determined as holocellulose (mixtures between cellulose and hemicelluloses). The content of holocellulose was determined according to the method presented in detail in our publication [28] as residues insoluble in $\mathrm{NaOH}$. The lignin content was determined as solid weight after the reaction with $\mathrm{H}_{2} \mathrm{SO}_{4}(72 \%)$.

\subsubsection{Elemental Analysis and Ash of Briquettes}

The elemental composition of the obtained briquettes, expressed as percentage content on dry basis of carbon, hydrogen, nitrogen, oxygen, and sulphur, was determined by Flash EA 2000 CHNS/O analyzer (Thermo Fisher Scientific, Waltham, MA, USA). The ash was determined by drying in the oven at $600{ }^{\circ} \mathrm{C}$ for $5 \mathrm{~h}$ a quantity of briquettes, and the remaining solids were quantified.

\subsubsection{Metals Determination}

Metals concentrations were determined according to the 16968:2015 standard [30], by the digestion of samples with a mixture of $65 \%$ nitric acid and $30 \%$ hydrogen peroxide in a closed polytetrafluoroethylene (PTFE) vessel, using a microwave digestion system (Speedwave MWS-3+, Berghof, Eningen, Germany), followed by the metals determination using an ICP-OES Optima 5300 DV (Perkin Elmer, Woodbridge, ON, USA).

\subsubsection{Mercury and Chlorine Determination}

The measurements of mercury from briquettes samples were carried out using an Automated Direct Hg Analyzer Hydra-C (Teledyne Instruments, Leeman Labs, Mason, $\mathrm{OH}$, USA), based on thermal desorption atomic absorption spectrometry. 
The Hydra-C Hg Analyzer includes a furnace module where the sample is dried and decomposed. The final decomposition products pass through a mercury amalgamator which collects $\mathrm{Hg}$. By heating of amalgamation tube, mercury is released and carried to the atomic absorption spectrometer. The absorbance signal for $\mathrm{Hg}$ was identified at a wavelength of $253.65 \mathrm{~nm}$. The chlorine determination was performed according to ISO 16994 (2016) [31].

\subsubsection{Determination of the Energy Consumption for Vineyard Waste Briquetting}

For determining the energy consumption of each technological step used in the briquetting technology, a Voltcraft Energy-Logger 4000 consumption meter (Voltcraft) was used. Through these counters all devices were fed: coarse and fine chopping of the vineyard, sieving and separation, and briquetting steps. The equipment measured the energy consumption, and the results were transferred to a PC.

\subsection{Structural Characterization of Briquettes}

\subsubsection{TGA/DTG Analysis}

The thermal decomposition and derivative thermogravimetric (DTG) analysis of briquettes was determined by using a TA Instruments SDT O 600 (TA Instruments, New Castle, DE, USA) with temperature ranging from 30 to $1000^{\circ} \mathrm{C}$ at $10^{\circ} \mathrm{C}$ per minute. A mass of $7.65 \pm 0.3 \mathrm{mg}$ of the dried samples (SB variety) was used for test, and the experiment was conducted under a nitrogen atmosphere. The experiments were repeatable with a standard deviation in peak temperature value.

\subsubsection{X-ray Diffraction (XRD)}

The X-ray diffraction (XRD) patterns were performed using a D8 Advance diffractometer (Bruker, Karlsruhe, Germany), operating at $40 \mathrm{kV}$ and $35 \mathrm{~mA}$, with $\mathrm{CuK} \alpha$ radiation $(\lambda=1.5406 \AA)$, at room temperature. The crystallinity index (CrI) was calculated using Equation (1).

$$
\operatorname{CrI}(\%)=\left(\frac{\mathrm{I}_{\mathrm{c}}}{\mathrm{I}_{\mathrm{am}}}\right) \times 100
$$

where $I_{C}$ is the maximum intensity of the (002) diffraction peak at a 20 angle close to $22^{\circ}$, and $\mathrm{I}_{\mathrm{am}}$ is the intensity at a 20 angle close to $15^{\circ}$, representing the amorphous part of the sample. The degree of crystallinity (DC) was calculated as the relationship between the crystalline and amorphous regions using Equation (2).

$$
\mathrm{DC}(\%)=\left(\frac{F_{c}}{F_{a}+F_{c}}\right) \times 100
$$

where DC is the degree of crystallinity, $F_{c}$ and $F_{a}$ are the areas of the crystalline and amorphous regions [32,33].

\subsection{Fuel Indexes Estimation}

The fuel indexes were estimated based on the metal contents according to the Sommersacher method [34]. The fuel indices estimated were: (i) $\mathrm{NO}_{x}$ emissions, calculated on the basis of the nitrogen content of the briquettes; (ii) aerosol emissions, calculated from the sum of the concentrations of $\mathrm{K}, \mathrm{Na}, \mathrm{Zn}$ and $\mathrm{Pb}$; (iii) the risk of corrosion at high temperatures, calculated from the $2 \mathrm{~S} \mathrm{Cl}^{-1}$ molar ratio; (iv) problems caused by melting ash were calculated from the $\mathrm{Si}(\mathrm{Ca}+\mathrm{Mg})^{-1}$ molar ratio; (v) $\mathrm{HCl}$ and $\mathrm{SO}_{2}$ emissions were calculated from the molar ratio of $(\mathrm{K}+\mathrm{Na})[\mathrm{x} \cdot(2 \mathrm{~S}+\mathrm{Cl})]^{-1}$.

\subsection{Combustion Experiments}

Classical heat storage was used to test the gaseous emissions. The flue gases were measured by using a flue gas analyzer (Testo, $350 \mathrm{XL}$, Titisee-Neustadt, Germany) according to the EN 15259 (2007) standard [35] to measure $\mathrm{O}_{2}$ (oxygen), $\mathrm{CO}$ (carbon monoxide), $\mathrm{CO}_{2}$ 
(carbon dioxide), $\mathrm{NO}$ (nitrogen oxide), $\mathrm{NO}_{\mathrm{X}}$ (nitrogen oxides), and $\mathrm{SO}_{2}$ (sulphur dioxide) contents. All tests were carried out in a fixed bed stove [29].

\subsection{Statistics}

For the statistical processing of the data, the XLStat Microsoft Excel (software BASIC+, 2019.3.2) plug-in (Addinsoft, Paris, France) was used. Tukey method for varieties comparison was used to determine the difference between them. Significance was declared at $p<0.05$ for all statistical analyses. The a, b, c, d, e, f, and g letters indicate statistically significant difference at $p<0.05$.

\section{Results and Discussion}

\subsection{Energy Consumption for Briquetting of Vineyard Waste}

The vineyard wastes were collected from north-west of Romania, a region with a high production of wine. The total energy consumption, briquetting time and quantity of briquetting were considered for the determination of the energy consumption and the capacity of the briquetting equipment. The moisture of vineyard wastes was adjusted to $10 \%$. The energy consumption is crucial for analyzing how much energy was consumed in each technological step. Table 1 presents the results obtained for energy consumption in the briquetting process.

Table 1. Specific energy consumption and working capacity of the briquetting machine fed with vineyard wastes. (Data represents means \pm standard deviations, $n=3$ parallel measurement).

\begin{tabular}{|c|c|c|c|c|c|c|}
\hline \multirow{2}{*}{$\begin{array}{l}\text { Biomass } \\
\text { Variety }\end{array}$} & \multirow{2}{*}{$\begin{array}{l}\text { Amount of } \\
\text { Briquettes } \\
\text { (kg) }\end{array}$} & \multirow{2}{*}{$\begin{array}{c}\text { Energy } \\
\text { Consumption } \\
(\mathbf{k W h})\end{array}$} & \multirow{2}{*}{$\begin{array}{l}\text { Briquetting } \\
\text { Time } \\
\text { (min) }\end{array}$} & \multicolumn{2}{|c|}{ Specific Energy Consumption } & \multirow{2}{*}{$\begin{array}{c}\text { Capacity of } \\
\text { Briquetting } \\
\text { Machine } \\
\left(\mathrm{kg} \mathrm{h}^{-1}\right)\end{array}$} \\
\hline & & & & $\left(\mathrm{kWh} \mathrm{kg}^{-1}\right)$ & $\left(\mathrm{MJ} \mathrm{kg}^{-1}\right)$ & \\
\hline $\mathrm{PN}$ & $39.03 \pm 4.78^{\mathrm{a}}$ & $3.695 \pm 0.45^{\mathrm{a}}$ & $10.0 \pm 1.22^{a}$ & $0.0946 \pm 0.01^{\mathrm{a}}$ & $0.340 \pm 0.04^{a}$ & $232.14 \pm 28.4^{\mathrm{a}}$ \\
\hline $\mathrm{MO}$ & $36.42 \pm 4.46^{\mathrm{ab}}$ & $3.190 \pm 0.39 a b$ & $9.2 \pm 1.11^{a b}$ & $0.0876 \pm 0.01^{a}$ & $0.315 \pm 0.04^{\mathrm{a}}$ & $237.52 \pm 29.0^{a}$ \\
\hline FN & $24.05 \pm 2.95^{c}$ & $2.119 \pm 0.26^{c}$ & $6.0 \pm 0.73^{c}$ & $0.0881 \pm 0.01^{\mathrm{a}}$ & $0.317 \pm 0.03^{\mathrm{a}}$ & $239.70 \pm 24.0^{\mathrm{a}}$ \\
\hline FA & $37.54 \pm 4.59 \mathrm{ab}$ & $3.262 \pm 0.40^{a b}$ & $9.5 \pm 1.16^{\mathrm{ab}}$ & $0.0869 \pm 0.01^{a}$ & $0.313 \pm 0.04$ & $235.10 \pm 28.1^{a}$ \\
\hline FR & $29.36 \pm 4.59 \mathrm{abc}$ & $2.633 \pm 0.32^{b c}$ & $7.3 \pm 0.89 \mathrm{bc}$ & $0.0897 \pm 0.01^{\mathrm{a}}$ & $0.323 \pm 0.03^{a}$ & $239.44 \pm 29.3^{\mathrm{a}}$ \\
\hline CS & $27.39 \pm 3.35^{b c}$ & $2.552 \pm 0.31 \mathrm{bc}$ & $7.0 \pm 0.75^{b c}$ & $0.0932 \pm 0.01^{\mathrm{a}}$ & $0.335 \pm 0.04^{\mathrm{a}}$ & $231.98 \pm 28.4^{\mathrm{a}}$ \\
\hline SB & $29.74 \pm 3.63^{a b c}$ & $2.700 \pm 0.33^{a b c}$ & $7.5 \pm 0.91^{a b c}$ & $0.0908 \pm 0.01^{\mathrm{a}}$ & $0.327 \pm 0.04^{\mathrm{a}}$ & $235.12 \pm 28.7^{\mathrm{a}}$ \\
\hline BB & $32.67 \pm 3.99 a b c$ & $2.898 \pm 0.35^{\mathrm{abc}}$ & $8.0 \pm 0.98^{a b c}$ & $0.0887 \pm 0.01^{\mathrm{a}}$ & $0.319 \pm 0.04^{\mathrm{a}}$ & $244.12 \pm 21.3^{\mathrm{a}}$ \\
\hline
\end{tabular}

Note: Values indicated with different letters are significantly different from each other at $p \leq 0.05$ levels, whereas same letters show no significant differences $(p>0.05)$. Different letters of each column show a significant difference at the level of $p \leq 0.05$.

The experimental data shows that the maximum energy consumption was obtained for the PN variety $\left(0.340 \mathrm{MJ} \mathrm{kg}^{-1)}\right.$, and the minimum for the FA variety $\left(0.313 \mathrm{MJ} \mathrm{kg}^{-1}\right)$. According to the study of Srivastava et al. [36], the energy required for obtaining briquettes from the vegetable market waste was in the range of $17-20 \mathrm{kWh} \mathrm{t}^{-1}$ and the working capacity of the briquetting machine was in the range of $200-310 \mathrm{~kg} \mathrm{~h}^{-1}$. The working capacity of the briquetting machine of the wastes was of approximately $230 \mathrm{~kg} \mathrm{~h}^{-1}$. Additionally, Cesprini et al. [37] reported an energy consumption of $34-77 \mathrm{~kW} \mathrm{ton}{ }^{-1}$ for briquettes made from glued wood waste. Table 2 presents the results obtained for energy potential of each vineyard varieties used in this study.

The vineyard briquettes' energy potential confirms their great potential to be used as solid fuel. The statistical analysis for quantity used for briquettes and briquettes produced shows no significant difference between samples (confidence level $95 \%, p$-value $<0.05$ ).

\subsection{Analysis of the Briquettes Obtained from Vineyard Waste}

The content of cellulose, hemicelluloses, and lignin are presented in Figure 2. This information on the major components will help to understand results. Lignin content in briquettes ranges between 22.4 and $36.5 \%$, depending on the variety. The amount of lignin was critical for the briquetting process because the lignin acts as a binding agent and determines the quality of the final product. According to the study of Afra et al. [38], the content of $9 \%$ lignin can substantially improve the calorific value of the biomass. The content of cellulose was between 30.2 and $36.2 \%$ and the content of hemicellulose was of 
16.5-24.3\%. The content of cellulose and lignin are the most important components that affect the combustion process. According to Gani et al. [39], a high content of cellulose in briquettes accelerates the burning and, conversely, the content of lignin has the opposite effect [39]. The present study demonstrates that the use of natural lignin binder leads to obtaining more economical and cheap biobriquettes. The effect of cellulose and lignin content from briquettes will be evaluated in the combustion process presented below.

Table 2. Quantity of briquettes produced from vineyard wastes and energy potential of each variety. (Data represents means \pm standard deviations, $n=3$ parallel measurement).

\begin{tabular}{|c|c|c|c|c|}
\hline \multirow{2}{*}{ Variety } & \multirow{2}{*}{$\begin{array}{l}\text { Quantity Used } \\
\text { for Briquettes, } \\
\quad\left(\mathrm{kg} \mathrm{ha}^{-1}\right)\end{array}$} & \multirow{2}{*}{$\begin{array}{c}\text { Quantity of Briquettes } \\
\text { Produced, } \\
\left(\mathrm{kg} \mathrm{ha}^{-1}\right)\end{array}$} & \multicolumn{2}{|c|}{$\begin{array}{l}\text { Energy Potential } \\
{\left[\mathrm{MJ}\left(\mathrm{kg}^{-1} \mathrm{ha}^{-1}\right)\right]}\end{array}$} \\
\hline & & & Higher & Lower \\
\hline $\mathrm{PN}$ & $821.70 \pm 100.6$ & $739.53 \pm 90.5$ & $13.975 \pm 1.71$ & $12.908 \pm 1.58$ \\
\hline $\mathrm{MO}$ & $876.64 \pm 107.4$ & $788.97 \pm 96.6$ & $14.474 \pm 1.77$ & $13.351 \pm 1.64$ \\
\hline $\mathrm{FN}$ & $737.18 \pm 90.3$ & $663.46 \pm 81.2$ & $12.649 \pm 1.55$ & $11.694 \pm 1.43$ \\
\hline FA & $672.43 \pm 82.4$ & $605.19 \pm 74.1$ & $11.505 \pm 1.41$ & $10.665 \pm 1.30$ \\
\hline FR & $683.67 \pm 83.7$ & $615.30 \pm 75.3$ & $11.765 \pm 1.44$ & $10.935 \pm 1.34$ \\
\hline CS & $674.06 \pm 82.6$ & $606.65 \pm 74.3$ & $11.522 \pm 1.41$ & $10.686 \pm 1.31$ \\
\hline SB & $689.93 \pm 84.5$ & $620.94 \pm 76.0$ & $11.964 \pm 1.46$ & $11.144 \pm 1.36$ \\
\hline $\mathrm{BB}$ & $664.45 \pm 81.4$ & $598.00 \pm 72.2$ & $11.386 \pm 1.39$ & $10.592 \pm 1.35$ \\
\hline
\end{tabular}

Note: values in the same row that do not share a letter are not significantly different at $p$-value $<0.05$.

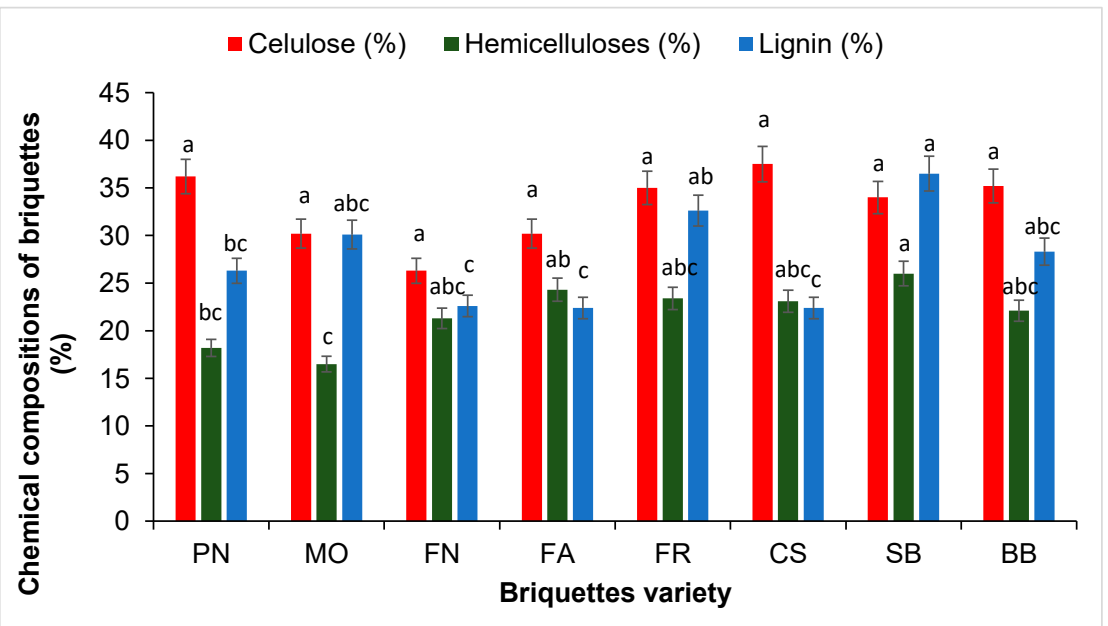

Figure 2. Chemical compositions of briquettes. Each point is the mean \pm standard deviation $(n=3)$. The means with different letters $(\mathrm{a}-\mathrm{c})$ above the bars indicate significant differences based on Tukey's test $(p<0.05)$.

Table 3 shows the proximate analysis of the obtained briquettes. The content of N, S, Cl, and ash were compared with the limits imposed by the existing standards. All briquettes samples respect the limit imposed by ISO 17225-7 and ISO 17225-3 standards [40,41]. The calorific value of the obtained briquettes was already presented in our recent paper [26] and all the samples have a gross calorific value of around $19 \mathrm{MJ} \mathrm{kg}^{-1}$ and a net calorific value of around $17 \mathrm{MJ} \mathrm{kg}^{-1}$. The high calorific value is important for longer burning time and to release more heat [42].

The chemical composition of biomass has an important role for its energy value because it consists of organic mass $(\mathrm{C}, \mathrm{H}, \mathrm{N}, \mathrm{S}, \mathrm{O})$, inorganic mass (the chemical elements in the ash that influences the energy characteristics), and the moisture. The higher $\mathrm{C}$ and $\mathrm{H}$ content is correlated with the higher the calorific value. On the other hand, the content of $\mathrm{O}$ must be as low as possible. Besides the elements that have a direct effect on the level of harmful emissions resulting from the combustion of solid biofuels, i.e., $\mathrm{S}, \mathrm{N}$ and $\mathrm{Cl}$, the ash content should be considered [43]. In all the samples, the $\mathrm{S}(<0.04 \%)$ and $\mathrm{N}(<1.5 \%)$ contents 
fitted into the standard requirement of briquettes made from wood. The low ash content showed that the obtained briquettes are suitable for combustion. The Tukey test for $\mathrm{N}$ and ash content shows a strong significance between samples ( $p$-value $<0.05)$. The major $(\mathrm{Al}$, $\mathrm{Ca}, \mathrm{Fe}, \mathrm{K}, \mathrm{Mg}, \mathrm{Na}, \mathrm{P}$, and $\mathrm{Si}$ ) and the minor (As, Ba, Cd, Co, Cr, Cu, Hg, Mn, Mo, Ni, Sb, Ti, and $\mathrm{Zn}$ ) elements form the ash components [44]. These elements are important for the ash melting, leading to the formation of deposits, aerosols emissions and corrosion of boilers. The high $\mathrm{Ca}$ and $\mathrm{Mg}$ content increases the melting point of ash, while $\mathrm{Cl}^{-}$and alkali metals significantly decreases it, leading to the formation of slag in the combustion chamber.

Table 3. Chemical composition of briquettes (mean \pm standard deviation, $n=3$ ).

\begin{tabular}{|c|c|c|c|c|c|c|c|c|}
\hline Variety & C & $\mathbf{H}$ & $\mathbf{O} *$ & $\mathbf{N}$ & S & $\mathrm{Cl}$ & Ash & DS ** $(\%)$ \\
\hline PN & $46.9 \pm 1.2^{\mathrm{a}}$ & $5.75 \pm 0.1^{\mathrm{a}}$ & $46.38 \pm 1.3^{\mathrm{a}}$ & $0.94 \pm 0.05^{b}$ & $0.033 \pm 0.01^{\mathrm{a}}$ & $0.06 \pm 0.01^{\mathrm{a}}$ & $3.18 \pm 0.02^{\mathrm{a}}$ & $92.92 \pm 1.8^{\mathrm{a}}$ \\
\hline $\mathrm{MO}$ & $46.4 \pm 1.6^{a}$ & $5.69 \pm 0.2^{a}$ & $47.01 \pm 1.2^{\mathrm{a}}$ & $0.86 \pm 0.02 \mathrm{bc}$ & $0.036 \pm 0.01^{a}$ & $0.04 \pm 0.01^{\mathrm{a}}$ & $2.09 \pm 0.04^{d}$ & $93.07 \pm 2.0^{\mathrm{a}}$ \\
\hline FN & $48.2 \pm 1.8^{\mathrm{a}}$ & $5.84 \pm 0.1^{\mathrm{a}}$ & $44.77 \pm 1.6^{\mathrm{a}}$ & $1.15 \pm 0.04^{\mathrm{a}}$ & $0.042 \pm 0.01^{\mathrm{a}}$ & $0.07 \pm 0.01^{\mathrm{a}}$ & $3.27 \pm 0.03^{a}$ & $93.48 \pm 2.2^{\mathrm{a}}$ \\
\hline FA & $47.1 \pm 1.2^{\mathrm{a}}$ & $5.70 \pm 0.4^{\mathrm{a}}$ & $46.40 \pm 1.4^{\mathrm{a}}$ & $0.76 \pm 0.03^{c}$ & $0.038 \pm 0.01^{\mathrm{a}}$ & $0.05 \pm 0.02^{\mathrm{a}}$ & $3.08 \pm 0.02^{b}$ & $94.42 \pm 1.8^{\mathrm{a}}$ \\
\hline FR & $47.2 \pm 1.4^{\mathrm{a}}$ & $5.66 \pm 0.3^{a}$ & $46.19 \pm 1.3^{\mathrm{a}}$ & $0.91 \pm 0.02^{b c}$ & $0.037 \pm 0.01^{\mathrm{a}}$ & $0.06 \pm 0.01^{\mathrm{a}}$ & $2.99 \pm 0.05^{b}$ & $95.48 \pm 2.3^{\mathrm{a}}$ \\
\hline CS & $47.0 \pm 1.2^{\mathrm{a}}$ & $5.67 \pm 0.2^{a}$ & $46.36 \pm 1.5^{\mathrm{a}}$ & $0.93 \pm 0.08^{b}$ & $0.037 \pm 0.01^{\mathrm{a}}$ & $0.06 \pm 0.01^{a}$ & $3.05 \pm 0.04^{b}$ & $94.57 \pm 2.4^{\mathrm{a}}$ \\
\hline SB & $47.7 \pm 1.6^{\mathrm{a}}$ & $5.66 \pm 0.1^{\mathrm{a}}$ & $45.61 \pm 1.3^{\mathrm{a}}$ & $0.99 \pm 0.07^{b}$ & $0.044 \pm 0.01^{\mathrm{a}}$ & $0.07 \pm 0.01^{\mathrm{a}}$ & $3.05 \pm 0.03^{b}$ & $96.66 \pm 2.3^{\mathrm{a}}$ \\
\hline BB & $47.3 \pm 1.8^{a}$ & $5.67 \pm 0.2^{\mathrm{a}}$ & $46.04 \pm 1.2^{\mathrm{a}}$ & $0.95 \pm 0.06^{b}$ & $0.041 \pm 0.01^{\mathrm{a}}$ & $0.07 \pm 0.01^{\mathrm{a}}$ & $2.68 \pm 0.02^{c}$ & $96.35 \pm 2.1^{\mathrm{a}}$ \\
\hline [29] & - & - & - & $\leq 1.5$ & $\leq 0.2$ & $\leq 0.10$ & $\leq 6$ & - \\
\hline [28] & - & - & - & $\leq 2.0$ & $\leq 0.3$ & $\leq 0.30$ & $\leq 10$ & - \\
\hline
\end{tabular}

Large amounts of $\mathrm{Ca}, \mathrm{K}$, and $\mathrm{Mg}$ were found in all the samples. The obtained results were compared with those from ISO 17225-7 [40] standard for non-woody briquettes and with the ISO 17225-3 [41] standard for wood briquettes. The existing standard imposed the limit for the content of $\mathrm{Ni}, \mathrm{Cr}, \mathrm{Cu}, \mathrm{Zn}, \mathrm{Cd}, \mathrm{Pb}, \mathrm{As}$, and $\mathrm{Hg}$. High quantities of $\mathrm{Ca}$, $\mathrm{K}$, and $\mathrm{Na}$ were found in all the samples. The contents of metals varied in the following ranges $\left(\mathrm{mg} \mathrm{kg}^{-1}\right): 61.3-86.2(\mathrm{Si})>58.03-412.5(\mathrm{Fe})>40.55-54.81(\mathrm{Al})>39.75-59.08(\mathrm{Na})>$ $18.96-41.83(\mathrm{Mn})>22.34-25.34(\mathrm{Cu})>24.42-27.54(\mathrm{~B})>9.63-23.55(\mathrm{Zn})>12.11-27.03(\mathrm{Ba})>$ 11.45-12.27 (Cr) > 10.57-10.70 (Co) $>9.73-10.05(\mathrm{Ni})>9.80-11.78(\mathrm{~Pb})>2.78-2.89(\mathrm{Cd})>$ 0.09-0.16 (As) (Table 4). The Cu content respected the standard for non-wood briquettes, but not the ISO 17225-3 for woody briquettes. The combustion process was affected by inorganic elements, like $\mathrm{K}, \mathrm{Na}, \mathrm{Si}, \mathrm{Mg}$, and $\mathrm{Al}$. According to Moreno et al. [45], the presence of $\mathrm{Ca}$ is beneficial for combustion, but the presence of $\mathrm{Si}$ decreases the melting point of ash and leads to fouling issues for combustion.

Table 4. Content of metals $\left(\mathrm{mg} \mathrm{kg}^{-1}\right)$ from briquettes obtained from vineyard residues (Data represents means \pm standard deviations, $n=3$ parallel measurement).

\begin{tabular}{|c|c|c|c|c|c|c|c|c|}
\hline Metals & PN & MO & FN & FA & FR & CS & SB & BB \\
\hline $\mathrm{Fe}$ & $58.0 \pm 0.3^{f}$ & $62.2 \pm 0.2^{\mathrm{e}}$ & $78.5 \pm 0.8^{c}$ & $279.0 \pm 1.5^{b}$ & $66.2 \pm 1.2^{\mathrm{d}}$ & $56.8 \pm 0.8^{f}$ & $412.5 \pm 1.2^{\mathrm{a}}$ & $41.4 \pm 0.6^{\mathrm{g}}$ \\
\hline $\mathrm{Ni}$ & $10.0 \pm 0.6^{\mathrm{a}}$ & $9.7 \pm 0.5^{\mathrm{a}}$ & $10.0 \pm 0.6^{\mathrm{a}}$ & $9.99 \pm 0.5^{\mathrm{a}}$ & $9.86 \pm 0.3^{a}$ & $9.81 \pm 0.7^{a}$ & $9.73 \pm 0.4^{\mathrm{a}}$ & $9.74 \pm 0.3^{a}$ \\
\hline $\mathrm{Cr}$ & $11.4 \pm 1.2^{\mathrm{a}}$ & $11.3 \pm 1.0^{\mathrm{a}}$ & $11.5 \pm 1.0^{\mathrm{a}}$ & $12.3 \pm 1.3^{\mathrm{a}}$ & $11.5 \pm 0.9^{a}$ & $11.5 \pm 1.0^{\mathrm{a}}$ & $11.9 \pm 1.1^{\mathrm{a}}$ & $11.6 \pm 1.2$ \\
\hline Co & $10.7 \pm 0.9$ a & $10.6 \pm 0.8$ a & $10.7 \pm 0.7$ a & $10.6 \pm 0.9^{a}$ & $10.7 \pm 1.0$ a & $10.6 \pm 1.2^{\mathrm{a}}$ & $10.7 \pm 1.1^{\text {a }}$ & $10.6 \pm 1.0^{\mathrm{a}}$ \\
\hline $\mathrm{Cu}$ & $25.2 \pm 1.2^{\mathrm{a}}$ & $22.3 \pm 1.5^{\mathrm{a}}$ & $25.1 \pm 1.3^{\mathrm{a}}$ & $22.7 \pm 1.1^{\text {a }}$ & $23.9 \pm 1.0^{\mathrm{a}}$ & $23.4 \pm 1.6^{\mathrm{a}}$ & $23.1 \pm 1.5^{\mathrm{a}}$ & $23.8 \pm 1.4^{\mathrm{a}}$ \\
\hline $\mathrm{Zn}$ & $18.0 \pm 0.9 \mathrm{bc}$ & $9.6 \pm 0.5^{\mathrm{e}}$ & $22.3 \pm 1.2 \mathrm{ab}$ & $23.6 \pm 1.8^{a}$ & $12.8 \pm 1.9 \mathrm{de}$ & $11.0 \pm 0.8^{\mathrm{e}}$ & $13.3 \pm 1.5^{\text {cde }}$ & $16.2 \pm 1.8^{\mathrm{cd}}$ \\
\hline $\mathrm{Cd}$ & $2.85 \pm 0.2^{\mathrm{a}}$ & $2.78 \pm 0.3^{\mathrm{a}}$ & $2.89 \pm 0.4^{\mathrm{a}}$ & $2.78 \pm 0.1^{a}$ & $2.84 \pm 0.4^{\mathrm{a}}$ & $2.89 \pm 0.5^{a}$ & $2.80 \pm 0.4^{\mathrm{a}}$ & $2.78 \pm 0.3^{a}$ \\
\hline $\mathrm{Pb}$ & $9.80 \pm 0.9^{a}$ & $9.83 \pm 0.6^{\mathrm{a}}$ & $10.2 \pm 0.9^{a}$ & $11.0 \pm 0.3^{a}$ & $10.0 \pm 0.2^{\mathrm{a}}$ & $10.0 \pm 0.8^{a}$ & $\begin{array}{l}2.80 \pm 0.4 \\
9.98 \pm 0.7 \text { a }\end{array}$ & $\begin{array}{l}2.8 \pm 0.3 \\
11.8 \pm 0.6^{a}\end{array}$ \\
\hline $\mathrm{Na}$ & $46.1 \pm 1.2 \mathrm{bc}$ & $44.5 \pm 2.0^{\mathrm{bcd}}$ & $39.8 \pm 2.1^{\mathrm{d}}$ & $59.1 \pm 0.8^{\mathrm{a}}$ & $46.9 \pm 1.6^{b}$ & $44.4 \pm 1.2^{\mathrm{bcd}}$ & $43.7 \pm 1.7 \mathrm{bcd}$ & $40.8 \pm 1.8^{\mathrm{cd}}$ \\
\hline $\mathrm{Mg}$ & $986.7 \pm 5.2^{\mathrm{a}}$ & $704.4 \pm 4.8^{h}$ & $838.3 \pm 5.6^{d}$ & $732.4 \pm 2.8^{g}$ & $813.0 \pm 3.6^{\mathrm{e}}$ & $856.7 \pm 5.2^{c}$ & $941.4 \pm 4.0^{\mathrm{b}}$ & $779.2 \pm 2.9^{\mathrm{f}}$ \\
\hline $\mathrm{K}$ & $1789.5 \pm 1.8^{\mathrm{h}}$ & $1833.1 \pm 2.6^{f}$ & $2147.9 \pm 3.1^{\mathrm{d}}$ & $2225.0 \pm 4.1^{\mathrm{c}}$ & $2019.5 \pm 5.6^{e}$ & $2401.9 \pm 4.9^{a}$ & $2331.0 \pm 4.6^{b}$ & $1810.0 \pm 1.8 \mathrm{~g}$ \\
\hline $\mathrm{Ca}$ & $3734.9 \pm 4.8^{\mathrm{e}}$ & $2306.2 \pm 3.1^{\mathrm{h}}$ & $4514.3 \pm 6.0^{b}$ & $4670.0 \pm 4.2^{\mathrm{a}}$ & $3706.8 \pm 4.7^{\mathrm{f}}$ & $3750.5 \pm 2.8^{d}$ & $3793.6 \pm 2.6^{c}$ & $3249.2 \pm 3.4 \mathrm{~g}$ \\
\hline $\mathrm{Mn}$ & $32.5 \pm 1.5^{\mathrm{bc}}$ & $19.0 \pm 1.2^{\mathrm{d}}$ & $30.7 \pm 1.8^{\mathrm{bc}}$ & $30.1 \pm 2.0^{\mathrm{bc}}$ & $28.4 \pm 1.6^{\mathrm{c}}$ & $20.0 \pm 1.4^{\mathrm{d}}$ & $41.8 \pm 1.6^{\mathrm{a}}$ & $35.1 \pm 1.4^{b}$ \\
\hline $\mathrm{Ba}$ & $15.8 \pm 0.8^{\mathrm{bc}}$ & $12.1 \pm 0.6^{\mathrm{d}}$ & $13.8 \pm 0.5^{\mathrm{bcd}}$ & $27.0 \pm 1.2^{\mathrm{a}}$ & $17.3 \pm 1.4^{b}$ & $12.0 \pm 1.3^{\mathrm{d}}$ & $14.8 \pm 1.2^{\mathrm{bcd}}$ & $12.8 \pm 1.0^{\mathrm{cd}}$ \\
\hline $\mathrm{Al}$ & $52.7 \pm 1.8^{\mathrm{a}}$ & $40.6 \pm 1.6^{b}$ & $54.8 \pm 1.9^{\mathrm{a}}$ & $45.4 \pm 1.2^{b}$ & $54.6 \pm 1.4^{\mathrm{a}}$ & $51.9 \pm 1.3^{a}$ & $43.6 \pm 1.0^{\mathrm{b}}$ & $41.9 \pm 1.2^{b}$ \\
\hline $\mathrm{B}$ & $27.5 \pm 1.2^{\mathrm{a}}$ & $24.4 \pm 1.0^{\mathrm{a}}$ & $26.8 \pm 1.3^{a}$ & $26.2 \pm 1.5^{a}$ & $27.1 \pm 1.0^{\mathrm{a}}$ & $26.4 \pm 0.9^{a}$ & $25.9 \pm 1.2^{\mathrm{a}}$ & $25.2 \pm 1.3^{a}$ \\
\hline
\end{tabular}


Table 4. Cont.

\begin{tabular}{|c|c|c|c|c|c|c|c|c|}
\hline Metals & PN & MO & FN & FA & FR & CS & SB & BB \\
\hline As & $0.15 \pm 0.1^{a}$ & $0.12 \pm 0.1^{a}$ & $0.15 \pm 0.1^{a}$ & $0.14 \pm 0.1^{\mathrm{a}}$ & $0.16 \pm 0.1^{a}$ & $0.13 \pm 0.1^{a}$ & $0.16 \pm 0.1^{\mathrm{a}}$ & $0.09 \pm 0.1^{\mathrm{a}}$ \\
\hline $\mathrm{Si}$ & $68.2 \pm 0.5^{c}$ & $72.3 \pm 0.7^{b}$ & $61.3 \pm 0.8^{\mathrm{d}}$ & $67.3 \pm 0.6^{c}$ & $86.2 \pm 0.8^{a}$ & $62.0 \pm 0.9^{d}$ & $62.0 \pm 0.8^{d}$ & $66.5 \pm 1.0^{\mathrm{c}}$ \\
\hline $\mathrm{Hg}$ & $<0.01$ & $<0.01$ & $<0.01$ & $<0.01$ & $<0.01$ & $<0.01$ & $<0.01$ & $<0.01$ \\
\hline
\end{tabular}

Note: Limits for $\mathrm{Ni} \leq 10, \mathrm{Cr} \leq 50, \mathrm{Cu} \leq 20, \mathrm{Zn} \leq 100, \mathrm{Cd} \leq 0.5, \mathrm{~Pb} \leq 10, \mathrm{As} \leq 1, \mathrm{Hg} \leq 0.1$, according to ISO 17225-7 standard [40]. Limits for $\mathrm{Ni} \leq 10, \mathrm{Cr} \leq 10, \mathrm{Cu} \leq 10, \mathrm{Zn} \leq 100, \mathrm{Cd} \leq 0.5, \mathrm{~Pb} \leq 10, \mathrm{As} \leq 1, \mathrm{Hg} \leq 0.1$ according to ISO 17225-3 standard [41]; values indicated with different letters are significantly different from each other at $p \leq 0.05$ levels, whereas same letters show no significant differences $(p>0.05)$.

\subsection{Estimation of Fuel Indexes of Briquettes}

Some metals present in briquettes, like $\mathrm{K}, \mathrm{Na}, \mathrm{Zn}, \mathrm{Pb}, \mathrm{Ca}$, and $\mathrm{Mg}$ could offer information about the combustion process, suggesting problems like slagging, corrosion, etc. In Table 5 are presented the results of fuel indices obtained.

Table 5. Estimation of fuel indices calculated based on the metal content determined from the obtained briquettes.

\begin{tabular}{|c|c|c|c|c|c|c|c|c|}
\hline Component & PN & MO & FB & FA & FR & CS & SB & BB \\
\hline $\begin{array}{l}\mathrm{K}+\mathrm{Na}+\mathrm{Zn}+ \\
\mathrm{Pb}\left(\mathrm{mg} \mathrm{kg}^{-1}\right)\end{array}$ & $1863 \pm 228.2^{a}$ & $\begin{array}{l}1897 \pm \\
232.33^{\mathrm{a}}\end{array}$ & $2220 \pm 271.9^{a}$ & $2319 \pm 284.0^{a}$ & $2089 \pm 255.8^{a}$ & $\begin{array}{c}2467 \pm \\
302.14^{\mathrm{a}}\end{array}$ & $2398 \pm 293.7^{a}$ & $1879 \pm 230.1^{a}$ \\
\hline $\begin{array}{c}2 \mathrm{~S} \mathrm{Cl}^{-1} \\
\left(\mathrm{~mol} \mathrm{~mol}^{-1}\right)\end{array}$ & $1.22 \pm 0.14^{\mathrm{b}}$ & $2.00 \pm 0.23^{a}$ & $1.33 \pm 0.16^{\mathrm{b}}$ & $1.69 \pm 0.2^{\mathrm{ab}}$ & $1.37 \pm 0.16^{\mathrm{b}}$ & $1.37 \pm 0.16^{b}$ & $1.39 \pm 0.16^{\mathrm{b}}$ & $1.30 \pm 0.15^{b}$ \\
\hline 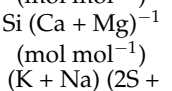 & $\begin{array}{l}0.067 \pm \\
0.008^{\mathrm{ab}}\end{array}$ & $0.074 \pm 0.009^{b}$ & $0.054 \pm 0.006^{\mathrm{ab}}$ & $0.051 \pm 0.005^{b}$ & $\begin{array}{l}0.067 \pm \\
0.008^{\mathrm{ab}}\end{array}$ & $\begin{array}{l}0.059 \mathrm{t} \\
0.007 \mathrm{ab}\end{array}$ & $\begin{array}{l}0.063 \pm \\
0.008^{\mathrm{ab}}\end{array}$ & $\begin{array}{l}0.062 \pm \\
0.007 \mathrm{ab}\end{array}$ \\
\hline $\begin{array}{c}\mathrm{Cl})^{-1} \\
\left(\mathrm{~mol} \mathrm{~mol}^{-1}\right)\end{array}$ & $3.23 \pm 0.39^{a b}$ & $3.13 \pm 0.37^{a b}$ & $3.04 \pm 0.36^{\mathrm{ab}}$ & $3.57 \pm 0.44^{\mathrm{ab}}$ & $3.27 \pm 0.40^{\mathrm{ab}}$ & $3.87 \pm 0.47^{\mathrm{a}}$ & $3.17 \pm 0.38^{a b}$ & $2.63 \pm 0.33^{b}$ \\
\hline $\begin{array}{c}\mathrm{Si} \mathrm{K} \mathrm{K}^{-1}(\mathrm{~mol} \\
\left.\mathrm{mol}^{-1}\right)\end{array}$ & $\begin{array}{l}0.053 \mathrm{t} \\
0.006^{\mathrm{abc}}\end{array}$ & $\begin{array}{l}0.055 \mathrm{t} \\
0.007 \mathrm{ab}\end{array}$ & $\begin{array}{l}0.040 \mathrm{t} \\
0.004 \mathrm{bcd}\end{array}$ & $\begin{array}{l}0.042 \underset{\mathrm{bcd}}{ \pm} \\
0.004 \mathrm{~b}\end{array}$ & $0.059 \pm 0.007^{a}$ & $0.036 \pm 0.004^{\mathrm{d}}$ & $\begin{array}{l}0.037 \underset{\mathrm{cd}}{ \pm} \\
0.00{ }^{\mathrm{cd}}\end{array}$ & $\begin{array}{l}0.051 \underset{\mathrm{abcd}}{ \pm} \\
0.007^{-}\end{array}$ \\
\hline
\end{tabular}

Note: the means with different letters (a-d) indicate a statistically significant difference based on the Tukey's test $(p<0.05)$.

The estimation of fuel indices offers the following information: due to the $\mathrm{N}$ content from briquettes, $\mathrm{NO}_{X}$ emissions are expected in all samples. The high content of $\mathrm{K}$ found in all the samples can lead to the formation of a huge quantity of aerosols. The corrosion risk calculated from the molar ratio $2 \mathrm{~S} \mathrm{Cl}^{-1}$ was higher than $1 \mathrm{~mol} \mathrm{~mol}^{-1}$ in all briquette samples; high corrosion risk of boilers is expected. The molar ratio between $(\mathrm{K}+\mathrm{Na})$ $(2 \mathrm{~S}+\mathrm{Cl})^{-1}$ is approximately $3 \mathrm{~mol} \mathrm{~mol}^{-1}$ in the briquette samples, which indicates a risk of high $\mathrm{SO}_{\mathrm{X}}$ emissions. The molar ration $\mathrm{Si} \mathrm{K}^{-1}$ is low due to the high potassium content, which shows a moderate risk of corrosion at high temperatures.

\subsection{Structural Characterization of Briquettes}

\subsubsection{X-ray Diffraction Analyses of the Briquettes}

The X-ray diffraction patterns of the fuel briquettes made from vineyard waste are presented in Figure 3. The peak intensities and peak broadening of the diffraction peaks did not significantly differ from one species to another. Any biomass is mainly composed by cellulose and hemicellulose, both embedded in lignin [46]. Hemicellulose and lignin are amorphous, while cellulose has both amorphous and crystalline components. The XRD technique offers information on the crystalline and the amorphous parts of cellulose, but not related to the presence of hemicellulose and lignin. The degree of crystallinity is one of the most important structure parameters, considering that the rigidity of cellulose fibers increases with the ratio of crystalline to amorphous regions. Two typical diffraction peaks determining the crystallinity of the samples were remarked at 20 around $15^{\circ}$ and $22^{\circ}$, corresponding to the minimum (101) and highest (002) peaks [47]. All the diffraction patterns displayed a well-defined main peak around $20=22^{\circ}$ indicating a type I cellulose as the main form of cellulose of the investigated samples. The crystalline index (CrI) values calculated based on the peak height method varied in the range of $19.3-24.0 \%$, while the degree of crystallinity (DC) assessed based on the area of crystalline and amorphous region ranged between $68.1-70.6 \%$. 


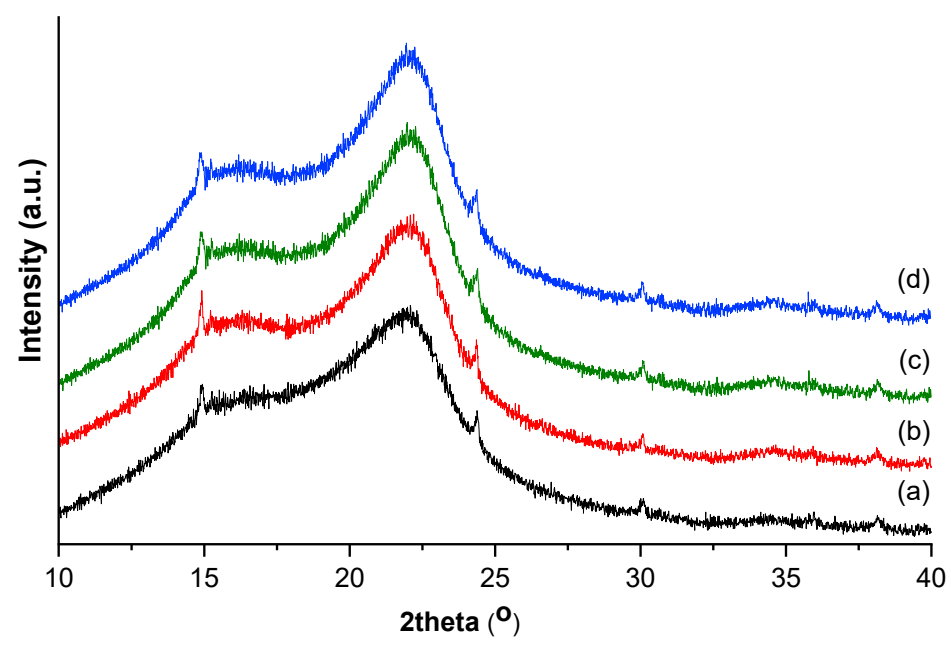

Figure 3. X-ray diffraction patterns of fuel briquettes made from vineyard waste: (a) BB, (b) FA, (c) $\mathrm{MO}$, and (d) SB.

\subsubsection{TGA of Briquettes}

The TGA/DTG curves of the obtained briquettes are presented in Figure 4. The briquettes were heated up from room temperature to $1000{ }^{\circ} \mathrm{C}$ in $\mathrm{N}_{2}$ atmosphere at a rate of $10{ }^{\circ} \mathrm{C} \mathrm{min}-1$. In the first stage (bellow $200{ }^{\circ} \mathrm{C}$ ), the mass loss was of $4.85 \pm 0.23 \%$, being attributed to the evaporation of water. The second stage $\left(200-700{ }^{\circ} \mathrm{C}\right)$ is the most important stage of briquettes heating and presents two characteristic peaks. The first peak appeared at $319.33^{\circ} \mathrm{C}$ and was attributed to the heating process and hemicellulose and crystalline cellulose elimination. Additionally, some dehydrogenation and decarbonization reaction can take place. The second peak at $418.63{ }^{\circ} \mathrm{C}$ and $40.45 \pm 3.40 \%$ from the biomass was lost due to the devolatilization phase and to the thermal degradation when carbon and volatiles were released. In the SB variety, the hemicellulose, cellulose, and lignin contents were $26 \%, 34 \%$, and $36.5 \%$, respectively. The decomposition of hemicellulose was faster than of cellulose and began at the temperature of $220{ }^{\circ} \mathrm{C}$ with physical loss of water, dehydration, and cleavage of the chain between heteropolymers. According to literature studies [48,49], hemicellulose is degraded first, then cellulose, and finally lignin, which are directly related to their chemical properties. The hemicellulose was decomposed within the temperature range of $220-315^{\circ} \mathrm{C}$. The decomposition of cellulose occurred in the temperature range of $315-400{ }^{\circ} \mathrm{C}$. Lignin was the most difficult to decompose and generally was decomposed slowly under a wide range of temperatures until $900{ }^{\circ} \mathrm{C}$. At $550{ }^{\circ} \mathrm{C}$, the linkage of the oxygen and hydrogen containing compounds are released from the lignin. According to Koskela et al. [50], the study of lignin pyrolysis shows that at temperatures ranging between 500 to $900{ }^{\circ} \mathrm{C}$, the benzene bonds from lignin are broken and lead to the formation of new aromatic clusters and favors char formation. The appearance of a small peak at $600{ }^{\circ} \mathrm{C}$ was attributed to the formation of biochar. In the last stage, the almost complete degradation (98.08\%) of briquettes occurred, corresponding to the char aggregation. The thermal decomposition of lignin results in the formation of quaiacyl, syringyl and p-hydroxylphenyl compounds which occur in several stages: melting of lignin, volatilization, and the breaking of $\beta-\mathrm{O}-4$ linkages from phenolic compounds. The complex structure of lignin requires higher temperature for decomposition than hemicellulose. The thermal decompositions of vineyard briquettes are in accordance with the reported literature for briquettes obtained from another lignocellulosic biomass [49]. The results presented suggest that a temperature higher than $1000^{\circ} \mathrm{C}$ is recommended for the complete degradation of briquettes. 


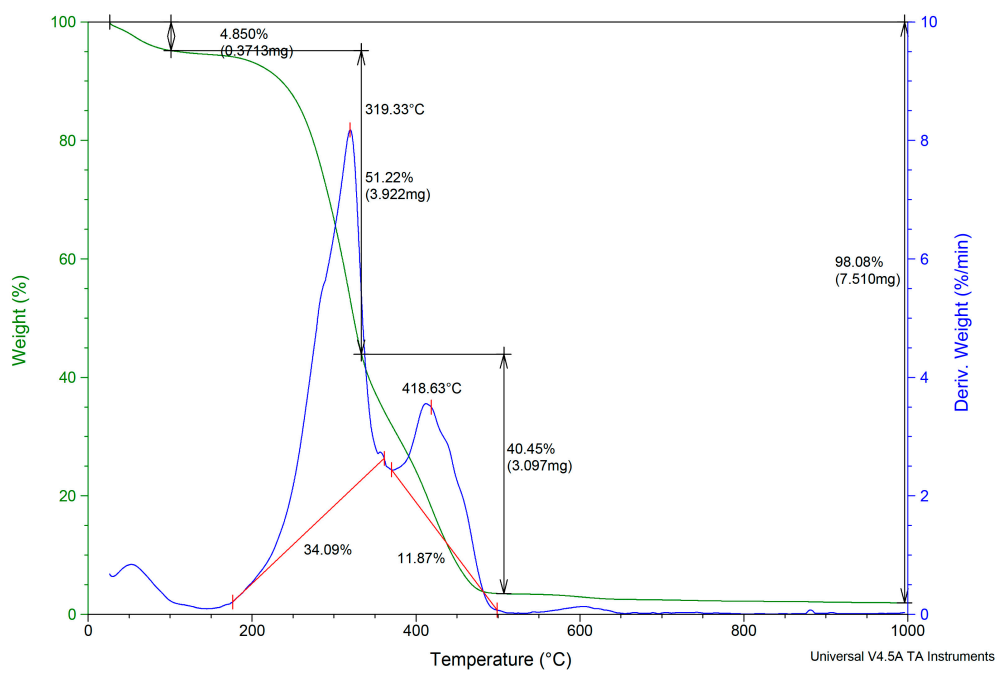

Figure 4. The TGA/DTG curves of the obtained briquettes for SB variety.

\subsection{Analysis of Gaseous Emissions from the Combustion of Briquettes}

$\mathrm{NO}_{\mathrm{X}}$ and $\mathrm{SO}_{2}$ emissions are the main gaseous pollutants. Due to presence of sulphur in the briquette composition, $\mathrm{SO}_{2}$ will be found in gaseous emissions. The emissions of $\mathrm{NO}_{X}, \mathrm{SO}_{2}$, and $\mathrm{CO}$ are presented in Table 6. The $\mathrm{NO}_{X}$ emissions were $444.7 \mathrm{mg} \mathrm{N}^{-1} \mathrm{~m}^{-3}$ and respect the limit of $500 \mathrm{mg} \mathrm{N}^{-1} \mathrm{~m}^{-3}$ required by the Romanian Law 462/1993 [51]. $\mathrm{NO}_{X}$ content was measured as the sum of nitrogen monoxide (NO) and nitrogen dioxide $\left(\mathrm{NO}_{2}\right)$ contents. The $\mathrm{SO}_{2}$ emissions were of $157.0 \mathrm{mg} \mathrm{N}^{-1} \mathrm{~m}^{-3}$, lower than the limit, and its presence was in accordance with the predictable fuel indices. Cong et al. [52] reported the following emissions of charcoal-based briquettes prepared using bio-tar as a binder: 113.2-225.6 $\mathrm{mg} \mathrm{N}^{-1} \mathrm{~m}^{-3}\left(\mathrm{NO}_{\mathrm{X}}\right)$ and $22.4-33.1 \mathrm{mg} \mathrm{N}^{-1} \mathrm{~m}^{-3}\left(\mathrm{SO}_{2}\right)$. The $\mathrm{CO}$ emissions were of $2165 \mathrm{mg} \mathrm{N}^{-1} \mathrm{~m}^{-3}$, exceeding the limit imposed by law, due to incomplete burning and no excess of air. Roy and Corscadden [53] reported $\mathrm{CO}$ emissions for switched grass briquettes of $1718 \mathrm{mg} \mathrm{N}^{-1} \mathrm{~m}^{-3}$. Briquettes made from vineyards contain combustible elements such as carbon, hydrogen and sulphur and non-combustible elements such as nitrogen, oxygen, and ash. Sulphur has harmful effects on the combustion because it leads to the formation of sulphur oxides $\left(\mathrm{SO}_{2}\right.$ and $\left.\mathrm{SO}_{3}\right)$ which produce acids that attack the metal parts of the plant. It is also responsible for the phenomenon of acid rain. The sulphur content of the briquettes was low, which has led to a low concentration of $\mathrm{SO}_{2}\left(157 \mathrm{mg} \mathrm{N}^{-1} \mathrm{~m}^{-3}\right)$, a value that falls within the limits imposed by the standard. In order to eliminate the suphur before the burning of briquettes, experiments for desulphurization methods (reaction with lime) will be performed and the results will be the step for the following experiments.

Incomplete combustion of carbon leads to the formation of $\mathrm{CO}$. The high $\mathrm{CO}$ content (2165 $\mathrm{mg} \mathrm{N}^{-1} \mathrm{~m}^{-3}$ ) results from insufficient oxygen during combustion. Carbon burns in two stages: in the first stage there is an incomplete combustion which leads to the formation of $\mathrm{CO}$, and in the second stage there is an oxidation of $\mathrm{CO}$ to $\mathrm{CO}_{2}$. If there is not enough oxygen, only the first stage of the carbon combustion takes place, and this results in a high $\mathrm{CO}$ content when burning the lighters. The high content of $\mathrm{CO}$ can be attributed to a high content of lignin from the briquette composition and to the slow burning rate. The largest variations in the flue gas appear in the first measurements (15-20 min) after ignition, then the concentrations become relatively stable. 
Table 6. The gaseous emissions results from burning of obtained briquettes in a cogeneration plant.

\begin{tabular}{|c|c|c|c|c|c|c|c|c|c|c|}
\hline Exp. & $\mathrm{O}_{2}(\%)$ & $\begin{array}{l}\mathrm{T}_{\text {gas }} \\
\left({ }^{\circ} \mathrm{C}\right)\end{array}$ & $\begin{array}{c}\mathrm{CO} \\
\left(\mathrm{mg} \mathrm{N}^{-1} \mathrm{~m}^{-3}\right)\end{array}$ & $\mathrm{CO}_{\text {ref }}$ & $\begin{array}{c}\mathrm{NO} \\
\left(\mathrm{mg} \mathrm{N}^{-1} \mathrm{~m}^{-3}\right)\end{array}$ & $\mathrm{NO}_{\text {ref }}$ & $\begin{array}{c}\mathrm{NO}_{\mathbf{X}} \\
\left(\mathrm{mg} \mathrm{N} \mathrm{N}^{-1} \mathrm{~m}^{-3}\right)\end{array}$ & $\begin{array}{c}\mathrm{NO}_{\mathrm{Xref}} \\
\left(\mathrm{mg} \mathrm{N}^{-1} \mathrm{~m}^{-3}\right)\end{array}$ & $\begin{array}{c}\mathrm{SO}_{2} \\
\left(\mathrm{mg} \mathrm{N}^{-1} \mathrm{~m}^{-3}\right)\end{array}$ & $\begin{array}{c}\mathrm{SO}_{2 \text { ref }} \\
\left(\mathrm{mg} \mathrm{N}^{-1} \mathrm{~m}^{-3}\right)\end{array}$ \\
\hline 1 & 16.8 & 160.5 & 150 & 704 & 67 & 158 & 76.4 & 359.3 & 45.2 & 199.2 \\
\hline 2 & 16.4 & 160.0 & 346 & 1211 & 65 & 228 & 135.2 & 472.6 & 39.2 & 114.2 \\
\hline 3 & 16.9 & 159.8 & 632 & 2585 & 50 & 203 & 104.1 & 425.4 & 42.0 & 154.2 \\
\hline 4 & 17.2 & 160.3 & 134 & 241 & 147 & 264 & 307.0 & 552.1 & 16.0 & 0 \\
\hline 5 & 17.7 & 160.2 & 266 & 302 & 189 & 215 & 401.5 & 455.6 & 16.0 & 0 \\
\hline 6 & 12.2 & 158.5 & 802 & 1832 & 215 & 490 & 443.2 & 1011.8 & 16.0 & 0 \\
\hline 7 & 14.3 & 157.0 & 302 & 3812 & 11 & 142 & 27.0 & 340.4 & 67.1 & 155.3 \\
\hline 8 & 17.7 & 158.2 & 261 & 1938 & 23 & 168 & 49.6 & 368.6 & 16.0 & 33.2 \\
\hline 9 & 13.2 & 157.7 & 673 & 6046 & 20 & 183 & 45.2 & 405.9 & 42.0 & 354.2 \\
\hline 10 & 13.9 & 160.1 & 327 & 3182 & 18 & 177 & 40.8 & 397.6 & 46.0 & 458.2 \\
\hline 11 & 16.3 & 157.1 & 372 & 1708 & 13 & 62 & 31.4 & 144.2 & 14.0 & 20.6 \\
\hline 12 & 15.8 & 158.7 & 800 & 3571 & 34 & 151 & 72.0 & 321.6 & 39.0 & 200.6 \\
\hline 13 & 17.1 & 146.4 & 200 & 1011 & 50 & 252 & 103.8 & 526.0 & 31.7 & 350.1 \\
\hline Mean & 15.8 & 158.0 & 405 & 2165 & 69 & 207 & 141.3 & 444.7 & 33.0 & 157.0 \\
\hline
\end{tabular}

Limits for $\mathrm{CO} \leq 250 \mathrm{mg} \mathrm{N}^{-1} \mathrm{~m}^{-3}, \mathrm{NO} x \leq 500 \mathrm{mg} \mathrm{N}^{-1} \mathrm{~m}^{-3}, \mathrm{SO}_{2} \leq 2000 \mathrm{mg} \mathrm{N}^{-1} \mathrm{~m}^{-3}$ [51].

\section{Conclusions}

The conducted study shows that vineyard wastes can be converted into good quality briquettes. Solid briquettes from vineyard wastes represent a cleaner energy alternative, considering the large amount of waste produced annually and the possibility to mitigate the reduction of $\mathrm{CO}_{2}$ emissions and promote its production. Lignin from vineyard waste's structure was used as a binder in the briquetting process, without using any other binding compound. The composition of briquettes was chemically and structurally characterized.

The TGA-DGT analysis was used to evaluate the thermal decomposition behaviors of briquettes components. Different mass losses were obtained depending on the decomposition of hemicellulose, cellulose, and lignin components, and the following processes occurred as the temperature increased: drying, heating, devolatilization, and char aggregation. The high content of lignin helps the briquetting production but has a negative effect on burning. The content of inorganic matter influenced the flue gases and predicted the pollutants emission. The XRD analysis of briquettes offered information about the crystalline and amorphous parts of cellulose in the briquettes, but it did not provide information about hemicellulose and lignin. The identified emissions pollutants were carbon monoxide, sulphur dioxide, and nitrogen oxide. The concentration of $\mathrm{CO}$ exceeded the maximum allowed by Romanian law due to an incomplete combustion. The incomplete combustion is predicted from the TGA analysis that shows that the char formation occurred around $600{ }^{\circ} \mathrm{C}$ due to the smoldering effect.

Author Contributions: Conceptualization, L.S.; methodology, I.T. and P.C.; formal analysis, D.A.S., E.K., M.R. and O.C.; writing-reviewing and editing, L.S., E.K. and M.S.; visualization, D.E.D.; supervision, C.R. All authors have read and agreed to the published version of the manuscript.

Funding: This research was funded by the Competitiveness Operational Programme of the Ministry of European Funds, code MY SMIS 107874, and the article processing charge (APC) was funded by the Ministry of Research, Innovation and Digitization through Program 1-Development of the national research \& development system, Subprogram 1.2-Institutional performance-Projects that finance the RDI excellence, Contract no. 18PFE/30 December 2021.

Institutional Review Board Statement: Not applicable.

Informed Consent Statement: Not applicable.

Data Availability Statement: The dataset generated during and/or analyzed during the current study are available from the corresponding author on reasonable request.

Conflicts of Interest: The authors declare no conflict of interest. The funders had no role in the design of the study; in the collection, analyses, or interpretation of data; in the writing of the manuscript, or in the decision to publish the results. 


\section{References}

1. Avcioğlu, A.O.; Dayioğlu, M.A.; Tütker, U. Assessment of the energy potential of agricultural biomass residues in Turkey. Renew. Energy 2019, 138, 610-619. [CrossRef]

2. Nour, M.; Amer, M.; Elwardany, A.; Attia, A.; Li, X.; Nada, S. Pyrolysis, kinetics, and structural analyses of agricultural residues in Egypt: For future assessment of their energy potential. Clean. Eng. Technol. 2021, 2, 100080. [CrossRef]

3. Asamoah, B.; Josiane, N.; Gebrezgabher, S.; Odonkor, E.; Njenga, M. Fuel briquettes: Making business sense. Urban Agric. Mag. 2017, 32, 42-43.

4. Manandhar, A.; Mousavi-Avval, S.H.; Tatum, J.; Shrestha, E.; Nazemi, P.; Shah, A. Chapter Eighteen-Solid biofuels. In Biomass, Biofuels, Biochemicals, Green-Economy, Systems Analysis for Sustainability; Elsevier: Amsterdam, The Netherlands, 2022; pp. 343-370.

5. Kpalo, S.Y.; Zainuddin, M.F.; Manaf, L.A.; Roslan, A.M. A review of technical and economic aspects of biomass briquetting. Sustainability 2020, 12, 4609. [CrossRef]

6. Brunerova, A.; Roubik, H.; Brozek, M.; Dung, D.V.; Phung, L.D.; Hasanudin, U.; Iryani, D.A.; Herak, D. Briquetting of sugarcane bagasse as a proper waste management technology in Vietnam. Waste Manag. Res. 2020, 38, 1239-1250. [CrossRef]

7. Velusamy, S.; Subbaiyan, A.; Kandasamy, S.; Shanmugamoorthi, M.; Thirumoorthy, P. Combustion characteristics of biomass fuel briquettes from onion peels and tamarind shells. Arch. Environ. Occup. Health 2021, 1-12. [CrossRef]

8. Bot, B.V.; Tamba, J.G.; Sosso, O.T. Assessment of biomass briquette energy potential from agricultural residues in Cameroon. Biomass Convers. Biorefin. 2022, 1-13. [CrossRef]

9. Kizito, S.; Jjagwe, J.; Ssewaya, B.; Nekesa, L.; Tumutegyereize, P.; Zziwa, A.; Komakech, A.J. Biofuel characteristics of non-charred briquettes from dried fecal sludge blended with food market waste: Suggesting a waste-to-biofuel enterprise as a win-win strategy to solve energy and sanitation problems in slums settlements. Waste Manag. 2021, 140, 173-182. [CrossRef]

10. Fehse, F.; Kummich, J.; Schröder, H.-W. Influence of pre-treatment and variation of briquetting parameters on the mechanical refinement of spent coffee grounds. Biomass Bioenergy 2021, 152, 106201. [CrossRef]

11. Magnago, R.F.; Costa, S.C.; Ezirio, M.J.A.; Saciloto, V.G.; Parma, G.O.C.; Gasporotto, E.S.; Goncalves, A.C., Jr.; Tutida, A.Y.; Barcelos, R.L. Briquettes of citrus peel and rice husk. J. Clean. Prod. 2020, 276, 123820. [CrossRef]

12. Setter, C.; Costa, K.L.S.; Oliveira, T.J.P.; Mendes, R.F. The effect of kraft lignin on the physicochemical quality of briquettes produced with sugarcane bagasse and on the characteristics of the bio-oil obtained via slow pyrolysis. Fuel Process. Technol. 2020, 210, 106561. [CrossRef]

13. Petkovic, D. Technology for producing briquettes from wet biomass. In Encyclopedia of Renewable and Sustainable Materials; Hashmi, S., Choudhury, I.A., Eds.; Elsevier: Amsterdam, The Netherlands, 2020; Volume 1, pp. 901-907.

14. Ifa, L.; Yani, S.; Nurjannah, N.; Darnengsih, D.; Rusnaenah, A.; Mel, M.; Mahfud, M.; Kusuma, H.S. Techno-economic analysis of bio-briquette from cashew nut shell waste. Heliyon 2020, 6, e05009. [CrossRef] [PubMed]

15. Chungcharoen, T.; Srisang, N. Preparation and characterization of fuel briquettes made from dual agricultural waste: Cashew nut shells and areca nuts. J. Clean. Prod. 2020, 256, 120434. [CrossRef]

16. Bello, R.S.; Onilude, M.A. Effects of critical extrusion factors on quality of high density briquettes produced from sawdust admixture. Mater. Today Proc. 2021, 38, 949-957. [CrossRef]

17. Akolgo, G.A.; Awafo, E.A.; Essandoh, E.O.; Owusu, P.A.; Uba, F.; Adu-Poku, K.A. Assessment of the potential of charred briquettes of sawdust, rice and coconut husks: Using water boiling and user acceptability tests. Sci. Afr. 2021, 12, e00789. [CrossRef]

18. Granado, M.P.P.; Suhogusoff, Y.V.M.; Santos, L.R.O.; Yamaji, F.M.; Conti, A.C.D. Effects of pressure densification on strength and properties of cassava waste briquettes. Renew. Energy 2021, 167, 306-312. [CrossRef]

19. Kapen, P.T.; Tenkeu, M.N.; Yadjie, E.; Tchuen, G. Production and characterization of environmentally friendly charcoal briquettes obtained from agriculture waste: Case of Cameroon. Int. J. Environ. Sci. Technol. 2021, 1-8. [CrossRef]

20. Sunardi, S.; Djuanda, D.; Mandra, M.A.S. Characteristics of charcoal briquettes from agricultural waste with compaction pressure and particle size variation as alternative fuel. Int. Energy J. 2019, 19, 139-148.

21. Oliy, G.B.; Muleta, D.T. Characterization and determination of briquette fuel prepared from five variety of corn cob. Int. J. Sustain. Energy 2020, 3, 59-64.

22. Bot, B.V.; Sosso, O.T.; Tamba, J.G.; Lekane, E.; Bikai, J.; Ndame, M.K. Preparation and characterization of biomass briquettes made from banana peels, sugarcane bagasse, coconut shells and rattan waste. Biomass Convers. Biorefin. 2021, 1-10. [CrossRef]

23. Lubwama, M.; Yiga, V.A.; Muhairwe, F.; Kihedu, J. Physical and combustion properties of agricultural residue bio-char biocomposite briquettes as sustainable domestic energy sources. Renew. Energy 2020, 148, 1002-1016. [CrossRef]

24. Setter, C.; Ataide, C.H.; Mendes, R.F.; de Oliveira, T.J.P. Influence of particle size on the physico-mechanical and energy properties of briquettes produced with coffee husks. Environ. Sci. Pollut. Res. 2021, 28, 8215-8223. [CrossRef] [PubMed]

25. Tesfaye, A.; Workie, F.; Kumar, V.S. Production and characterization of coffee husk fuel briquettes as an alternative energy source. Adv. Mater. Sci. Eng. 2022, 2022, 1-13. [CrossRef]

26. Tenu, I.; Roman, C.; Senila, L.; Rosca, R.; Carlescu, I.; Baetu, M.; Arsenoaia, V.; Dumitrachi, E.P.; Corduneanu, O.R. Valorization of vine tendrils resulted from pruning as densified solid biomass fuel (Briquettes). Processes 2021, 9, 1409. [CrossRef]

27. Nagarajan, J.; Prakash, L. Preparation and characterization of biomass briquettes using sugarcane bagasse, corncob and rice husk. Mater. Today Proc. 2021, 47, 4194-4198. [CrossRef] 
28. Senila, L.; Kovacs, E.; Scurtu, D.A.; Cadar, O.; Becze, A.; Senila, M.; Levei, E.A.; Dumitras, D.E.; Tenu, I.; Roman, C. Bioethanol production from vineyard waste by autohydrolysis pretreatment and chlorite delignification via simultaneous saccharification and fermentation. Molecules 2020, 25, 2606. [CrossRef]

29. Senila, L.; Tenu, I.; Carlescu, I.; Corduneanu, O.R.; Dumitrachi, E.P.; Kovacs, E.; Scurtu, D.A.; Cadar, O.; Becze, A.; Senila, M.; et al. Sustainable biomass pellets production using vineyard wastes. Agriculture 2020, 10, 501. [CrossRef]

30. ISO 16968:2015; Solid Biofuels. Determination of Minor Elements. ISO: Geneva, Switzerland, 2015.

31. ISO 16994:2016; Solid Biofuel. Determination of Total Content of Sulphur and Chlorine. ISO: Geneva, Switzerland, 2016.

32. Segal, L.; Creely, J.J.; Martin, A.E.; Conrad, C.M. Am empirical method for estimating the degree of crystallinity of native cellulose using the X-ray diffractometer. Text. Res. J. 1959, 29, 786-794. [CrossRef]

33. Azizan, A.; Azmi, I.S.; Darim, R.A.; Jusri, N.A.A.; Jalil, R.; Rahman, M.F.A.; Salleh, R.M.; Ibrahim, N.; Salihon, J. Lignocellulosic ionic liquid pretreated biomaterials/biomass. Mater. Today Proc. 2021, 46, 1688-1692. [CrossRef]

34. Sommersacher, P.; Brunner, T.; Obernberger, I. Fuel indexes: A novel method for the evaluation of relevant combustion properties of new biomass fuels. Energy Fuels 2012, 26, 380-390. [CrossRef]

35. EN 15259:2007; Air Quality. Measurement of Stationary Source Emissions. Requirements for Measurement Sections and Site and for the Measurement Objective, Plan and Report. BSi: London, UK, 2007.

36. Srivastava, N.S.L.; Narnaware, S.L.; Makwana, J.P.; Singh, S.N.; Vahora, S. Investigating the energy use of vegetable market waste by briquetting. Renew. Energy 2014, 68, 270-275. [CrossRef]

37. Cesprini, E.; Greco, R.; Causin, V.; Urso, T.; Cavalli, R.; Cavalli, R.; Zanetti, M. Quality assessment of pellets and briquettes made from glue wood waste. Eur. J. Wood Wood Prod. 2021, 79, 1153-1162. [CrossRef]

38. Afra, E.; Abyaz, A.; Saraeyan, A. The production of bagasse biofuel briquettes and the evaluation of natural binders (LNFC, NFC, and lignin) effects on their technical parameters. J. Clean. Prod. 2021, 278, 123543. [CrossRef]

39. Gani, A.; Naruse, I. Effect of cellulose and lignin content on pyrolysis and combustion characteristic for several types of biomass. Renew. Energy 2007, 32, 649-661. [CrossRef]

40. ISO 17225-7; Solid Biofuels. Fuel Specifications and Classes-Part 7: Graded Non-Woody Briquettes. ISO: Geneva, Switzerland, 2014.

41. ISO 17225-3; Solid Biofuels. Fuel Specifications and Classes-Part 3: Graded Wood Briquettes. ISO: Geneva, Switzerland, 2021.

42. Bisen, K.S.; Sharma, P.; Gupta, B.; Baredar, P. Development and experimental characterization of energy efficient poultry litter \& plant weeds based briquettes (PLPWBB) by comparing with rice husk briquettes. Mater. Today Proc. 2021, 4, 5428-5432.

43. Nyakuma, B.B.; Johari, A.; Ahmad, A.; Abdullah, T.A.T. Thermogravimetric analysis of the fuel properties of empty fruit bunch briquettes. J. Teknol. 2014, 67, 79-82. [CrossRef]

44. Viczek, S.A.; Aldrian, A.; Pomberger, R.; Sarc, R. Origins of major and minor ash constituents of solid recovery fuel for coprocessing in the cement industry. Waste Manag. 2021, 126, 423-432. [CrossRef]

45. Moreno, A.I.; Font, R.; Conesa, J.A. Physical and chemical evaluation of furniture waste briquettes. Waste Manag. 2016, 49, 245-252. [CrossRef]

46. Taherzadeh, M.; Karimi, K. Pretreatment of lignocellulosic wastes to improve ethanol and biogas production: A Review. Int. J. Mol. Sci. 2008, 9, 1621-1651. [CrossRef]

47. Dlangamandla, N.; Ntwampe, S.K.O.; Angadam, J.O.; Itoba-Tombo, E.F.; Chidi, B.S.; Mekuto, L. Integrated hydrolysis of mixed agro-waste for a second generation biorefinery using Nepenthes mirabilis pod digestive fluids. Processes 2019, 72, 64. [CrossRef]

48. Dhyani, V.; Bhaskar, T. A comprehensive review on the pyrolysis of lignocellulosic biomass. Renew. Energy 2018, 129, 695-716. [CrossRef]

49. Volli, V.; Gollakota, A.R.K.; Shu, C.-M. Comparative studies on thermochemical behavior and kinetics of lignocellulosic biomass residues using TG-FTIR and Py-GC/MS. Sci. Total Environ. 2021, 792, 148392. [CrossRef] [PubMed]

50. Kskela, A.; Heikkilä, A.; Bergna, D.; Salminen, J.; Fabritius, T. Effects of briquetting and high pyrolysis temperature and hydrolysis lignin char properties and reactivity in $\mathrm{CO}-\mathrm{CO}_{2}-\mathrm{N}_{2}$ conditions. Minerals 2021, 11, 187. [CrossRef]

51. Law No. 462/1993 on Technical Requirements for Air Protection and Limits on Polluting Emissions from Stationary Sources. Available online: http:/ /legislatie.just.ro/Public/DetaliiDocument/3538 (accessed on 10 January 2022).

52. Cong, H.; Yao, Z.; Mašek, O.; Meng, H.; Sheng, C.; Wu, Y.; Zhao, L. Co-combustion, co-densification, and pollutant emission characteristics of charcoal-based briquettes prepared using bio-tar as a binder. Fuel 2021, 287, 119512. [CrossRef]

53. Roy, M.M.; Corscadden, K.W. An experimental study of combustion and emissions of biomass briquettes in a domestic wood stove. Appl. Energy 2012, 99, 206-212. [CrossRef] 